\title{
Species composition and habitat preferences of the nearshore fish fauna of Bonne Bay, Newfoundland
}

\author{
Arnault Le Bris ${ }^{1 *}$ id and Joseph S. Wroblewski
}

\begin{abstract}
Background: Determining biodiversity baseline is the first step toward establishing species monitoring and conservation programs. In this study we report on a 10-year survey of the fish fauna of Bonne Bay, a fjord surrounded by the Gros Morne National Park on the west coast of Newfoundland, Canada. The objectives of our study were: 1) to determine the fish fauna of Bonne Bay using standardized sampling methods; 2) to gather information on the habitats of fishes of conservation concern; and 3) to provide baseline information on Bonne Bay as a potential candidate for a National Marine Conservation Area (NMCA).

Methods: A survey of the fish fauna of the inner Bonne Bay was conducted each summer from 2002 to 2011 at multiple sites representing a range of fish habitats within the fjord. Sampling gears included two types of beach seine, gillnets with various mesh sizes and a bottom trawl. Species composition was statistically compared across sites within the fjord.

Results: We collected and identified 29 fish species from 17 families. Fish assemblages comprised anadromous, estuarine, and marine fish species, including a late-maturing type of winter skate (Leucoraja ocellata) that is rarely found in the adjacent waters of the northern Gulf of St. Lawrence. Similarity in species composition across sites reflected salinity, substrate composition, and presence of eelgrass (Zostera marina), but not the geographic distance between sites.

Conclusions: Bonne Bay's adjacency to a United Nations Educational, Scientific, and Cultural Organization (UNESCO) World Heritage Site, its diverse fish fauna that includes several species of conservation concern, its potential for education and enjoyment, and its stewardship by local people are suggestive of the future candidacy as a NMCA. The data presented here will help managers assess the potential of Bonne Bay as a National Marine Conservation Area.
\end{abstract}

Keywords: Cold-temperate fish fauna, Baseline survey, Newfoundland fjord, Marine conservation area evaluation

\section{Background}

Bonne Bay is a sub-arctic fjord surrounded by the Gros Morne National Park, a United Nations Educational, Scientific, and Cultural Organization (UNESCO) World Heritage Site on the west coast of Newfoundland, Canada (Fig. 1). The terrestrial ecosystem in Gros Morne National Park is protected by federal legislation

\footnotetext{
* Correspondence: arnault.lebris@mi.mun.ca

${ }^{1}$ Centre for Fisheries Ecosystems Research, Fisheries and Marine Institute of Memorial University of Newfoundland, St. John's, NL A1C 5R3, Canada Full list of author information is available at the end of the article
}

(Canada National Parks Act) designed for managing human activity in National Parks. This legislative mandate ends at the low-tide mark, and hence the marine ecosystem of Bonne Bay currently has no special protection. The bay is regulated by the usual federal laws for managing the coastal waters of Canada (Parsons 1993; Guénette and Alder 2007).

Despite the lack of special protection, the Bonne Bay marine ecosystem has become a focus for stewardship efforts by adjacent coastal communities because the fjord supports small boat fisheries for American lobster

(c) The Author(s). 2018 Open Access This article is distributed under the terms of the Creative Commons Attribution 4.0 International License (http://creativecommons.org/licenses/by/4.0/), which permits unrestricted use, distribution, and 


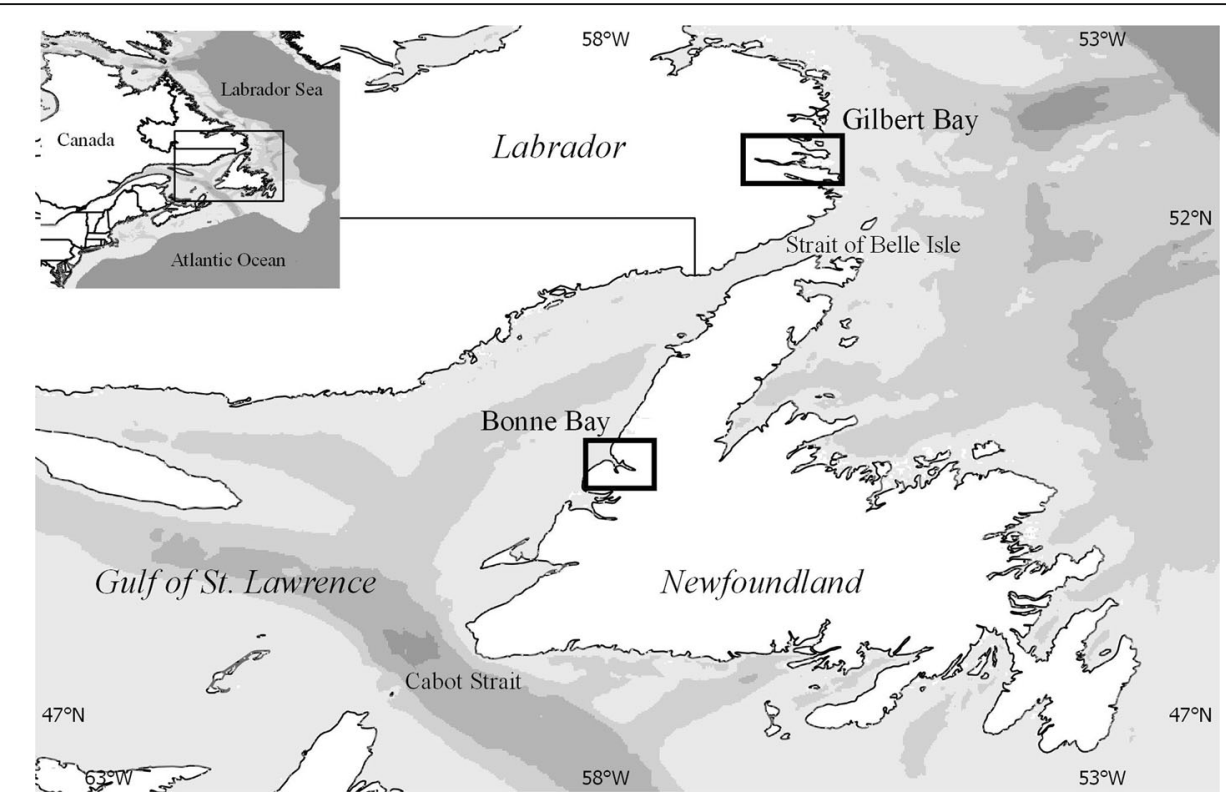

Fig. 1 Map showing the location of Bonne Bay in western Newfoundland and the location of Gilbert Bay in southeastern Labrador in relation to the Gulf of St. Lawrence

(Homarus americanus) and snow crab (Chionoecetes opilio), recreational fishing for Atlantic cod (Gadus morhua) and sea-run brook trout (Salvelinus fontinalis), pleasure boating, sailing, SCUBA diving, kayaking and bird-watching. The stewardship attitude held by commercial harvesters is helping to rebuild local stocks of lobster and snow crab. A two-year moratorium (2009-2010) on fishing snow crab in Bonne Bay was a conservation effort initiated by local harvesters. The closure allowed pre-recruit snow crab to reach maturity and reproduce before being harvested, increasing the productivity of the fishery. The establishment of a lobster conservation area in Trout River Bay on the southwestern boundary of Gros Morne National Park (Ennis 2011) was initiated by local harvesters, another example of stewardship of living marine resources.

While the terrestrial and freshwater ecosystems of Gros Morne National Park are being studied and monitored (Parks Canada Agency 2011), comparatively little is known about the marine ecosystem of Bonne Bay. Several species of marine mammals, reptiles and fish listed under the Species at Risk Act (SARA) have been observed in Bonne Bay (Wroblewski 2013), including the fin whale (Balaenoptera physalus; Atlantic population; "special concern"; COSEWIC 2005), the harbour porpoise (Phocoena phocoena; Northwest Atlantic population; "threatened"; COSEWIC 2006), the leatherback sea turtle (Dermochelys coriacea; "endangered"; COSEWIC 2012a), the spotted wolffish (Anarhichas minor, "threatened", COSEWIC 2012b), and the Atlantic wolffish (Anarhichas lupus; "Special Concern";
COSEWIC 2012c). Exploratory SCUBA diving surveys of the marine fauna and flora in Bonne Bay have been carried out (Hooper 1975) and there have been a few studies of the marine plants (South and Hooper 1980), invertebrates (Hooper 1996; Quijon and Snelgrove 2005), and fishes (Pottle et al. 1981). However, a systematic sampling to determine the fish fauna present in Bonne Bay had not been conducted prior to our study.

The outer basin of the Bonne Bay opens to the northeast Gulf of St. Lawrence (GSL). The GSL is a semi-enclosed sea with two openings to the Atlantic Ocean: the Strait of Belle Isle through which cold Labrador Sea waters enter the Gulf, and the Cabot Strait through which warmer Western Atlantic waters enter the Gulf. General information on the Northwest Atlantic fish fauna is available, but specific reference to Bonne Bay is limited (Scott and Scott 1988; Collette and Klein-MacPhee 2002). Fish stock abundance surveys carried out by Fisheries and Oceans Canada provide information on the fish fauna of the Gulf of St. Lawrence (Nozères et al. 2010; Chouinard and Dutil 2011). However, these depth-stratified, bottom-trawl surveys do not sample the shallow coastal zone $<20$ fathoms $(36 \mathrm{~m})$. As a result, there is no documentation of the fishes in bays and fjords of western Newfoundland.

In this study we report on a 10-year sampling effort to characterize the nearshore fish fauna of inner Bonne Bay using standardized sampling methods. Given the location of Bonne Bay in the northeast Gulf of St. Lawrence, south of the Strait of Belle Isle, which is a biogeographic boundary separating subarctic species along the 
Labrador coast from cold-temperate species along the Newfoundland coast (Steele 1975, 1983), we hypothesize that the fish fauna of inner Bonne Bay is composed of cold-temperate fishes near their northern range limit. This research provides baseline environmental information on Bonne Bay as a potential candidate for a National Marine Conservation Area.

\section{Methods}

\section{Study area}

Bonne Bay is a fjord shaped by multiple glacial events in the geological past (Shaw 2003). There are three main sources of freshwater draining off the boreal forested watershed into the bay: Deer Brook, Southeast Brook and Lomond River (Fig. 2). A shallow (14 m) sill near Norris Point separates the outer basin and South Arm from the inner basin composed of East Arm and Deer Arm (Fig. 2). A current-swept channel across the sill has a maximum depth of $26 \mathrm{~m}$. The maximum depth of East Arm is $230 \mathrm{~m}$ (Shaw 2003; Richards and de Young 2004).

The nearshore zone of inner Bonne Bay varies in bottom substrate type, bottom slope, vegetation coverage, seawater temperature and salinity. Fish collection sites were chosen to represent a range of fish habitats in the bay (Table 1). Initial sampling was conducted at four main sites (Sites 1, 2, 3 and 4). As the study progressed, three supplementary sites (Sites 2A, 3A and 4A) were added to increase the types of fish habitat sampled (Tables 1 and 2, Fig. 2). All sites were located in the inner part of the Bay as an underlying objective was to evaluate which species and which stages would cross the shallow sill.

\section{Oceanographic data collection}

Water column profiles of seawater temperature and salinity were recorded at each site before deployment of fish collection equipment (Table 1). Salinity and temperature were measured using a $\mathrm{YSI}^{\circ}$ Model $30 \mathrm{M}-100 \mathrm{FT}$ water quality probe. Bottom depth was measured using a Piranha ${ }^{\circ}$ Max 15 dual beam depth sounder. In June 2004 conductivity-temperature-depth (CTD) profiles at stations along the main axis of East Arm and South Arm were recorded using a Seabird Electronics Inc. SBE-25 CTD (see Figure 43, 44, 49 and 50 in Richards and de Young 2004). Moorings with $300 \mathrm{kHz}$ acoustic doppler current profilers (ADCP) were deployed between September 2002 and September 2006 on the sill to monitor temperature and salinity and the velocity of the water flowing across the sill (Richards and de Young 2004; de Young et al. 2005).

\section{Methods of collecting fishes}

The fish fauna of inner Bonne Bay was sampled during the last two weeks of June in the years 2002 to 2011. In 2009 sampling was also conducted during mid-October (Table 2). The sampling effort at the seven fish collection sites varied annually (Table 2). Fish caught were held in a tub filled with seawater until measured and released alive if possible. Fish were identified and measured for standard length (SL) to the nearest millimetre. Skates were measured for total length (TL) to the nearest millimetre. Proportions of mature individuals for each species were estimated based on size at maturity reported in the literature (Table 3).

To overcome sampling gear inefficiency and selectivity, several types of fish collection equipment were deployed (Methven et al. 2001; Hemingway and Elliott 2002). A $10 \mathrm{~m}$ wide by $1.5 \mathrm{~m}$ high beach seine with $10 \mathrm{~mm}$ stretch mesh throughout was used to sample intertidal waters along the shoreline at all seven sites with a tow length of $25 \mathrm{~m}$. A larger beach seine
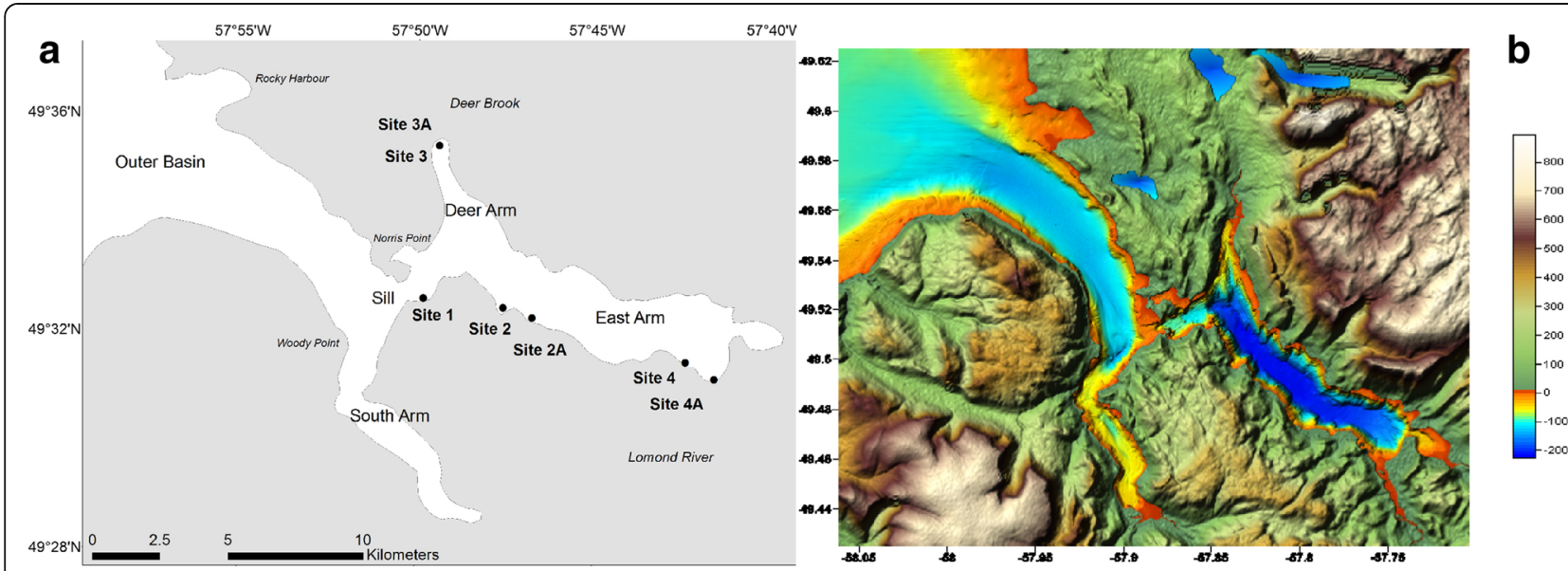

Fig. 2 a. Map of Bonne Bay showing location of the seven fish collection sites. Site 1 is locally known as inner Gadds Harbour; Site 2 is Norris Cove; Site 2A is Lords and Ladies Cove; Site 3 is Deer Brook delta; Site 3A is Deer Brook barachois; Site 4 is Lomond Cove; Site $4 A$ is Lomond River delta. b. Map of the topography and bathymetry of Bonne Bay 
Table 1 Description of the sampling sites. Depth, temperature and salinity measurements were taken at a distance of $50 \mathrm{~m}$ from shore (distance covered by the $25 \mathrm{~m}$ beach seine) on 29 June 2009. Surface and bottom measurements are shown for temperature and salinity

\begin{tabular}{|c|c|c|c|c|c|c|}
\hline Site \# & Site description & Subtidal substrate & $\begin{array}{l}\text { Depth } \\
(\mathrm{m})\end{array}$ & $\mathrm{T}\left({ }^{\circ} \mathrm{C}\right)$ & $\begin{array}{l}\text { Salinity } \\
\text { (ppt) }\end{array}$ & $\begin{array}{l}\text { Presence of } \\
\text { eelgrass }\end{array}$ \\
\hline 1 & Sheltered cove with pebble beach & Sand and silt with scattered boulders & 8.0 & $16.5 \& 7.6$ & $23 \& 29.8$ & No \\
\hline 2 & Exposed cove with pebble and cobble beach & $\begin{array}{l}\text { Hard with sand, pebbles and scattered } \\
\text { boulders }\end{array}$ & 20.0 & $16.4 \& 5$ & $23.7 \& 30.3$ & No \\
\hline $2 A$ & Similar to site 2 & $\begin{array}{l}\text { Hard with sand, pebbles and scattered } \\
\text { boulders }\end{array}$ & 10.0 & $11.7 \& 7.8$ & $28.6 \& 30.5$ & No \\
\hline 3 & $\begin{array}{l}\text { Delta of Deer Brook river with sand and } \\
\text { pebble beach }\end{array}$ & Sand and silt & 3.5 & $17.1 \& 12.4$ & $5.5 \& 24$ & Yes \\
\hline $3 A$ & Barachois: (shallow < 2 m lagoon) & Sand and silt & 0.5 & 20.3 & 1.8 & No \\
\hline 4 & Exposed cove with pebble and cobble beach & Sand and silt & 3.8 & $13.8 \& 9.9$ & $26.2 \& 28.1$ & Yes \\
\hline $4 \mathrm{~A}$ & $\begin{array}{l}\text { Delta of Lomond River with sand and pebble } \\
\text { beach }\end{array}$ & Sand and silt & 1.1 & $15.6 \& 12.7$ & $24.2 \& 27.2$ & Yes \\
\hline
\end{tabular}

measuring $25 \mathrm{~m}$ by $1.5 \mathrm{~m}$ in the wing, with $10 \mathrm{~mm}$ stretch mesh netting and a $5 \mathrm{~mm}$ stretch mesh in the cod-end, was deployed approximately $50 \mathrm{~m}$ from the shoreline using a boat, and pulled towards the shore by two groups of people about $17 \mathrm{~m}$ apart. Sampling with the $25 \mathrm{~m}$ beach seine was restricted to Site 2, Site 2A, Site 3, Site 4 and Site 4A (Table 2). Two gillnets were also deployed. A three-panel gillnet with stretch mesh sizes of $2.6 \mathrm{~cm}$ ( 1 in.), $3.8 \mathrm{~cm}$ (1.5 in.) and $5.1 \mathrm{~cm}(2$ in.) was deployed in shallow water and a single panel gillnet with stretch mesh size of $7.6 \mathrm{~cm}$ (3 in.) was deployed in deeper water, but not exceeding a depth of $100 \mathrm{~m}$. Gillnets were set during the evening, fished overnight and retrieved the following morning. Finally, a $4.9 \mathrm{~m}$ semi-balloon bottom trawl $(5.1 \mathrm{~m}$ head rope and $6.4 \mathrm{~m}$ foot rope) with nylon twine netting $(38 \mathrm{~mm}$ stretch

Table 2 Sampling effort at the seven fish collection sites within Bonne Bay during the decade 2002 to 2011: number of standardized tows with the $10 \mathrm{~m}$ beach seine, $25 \mathrm{~m}$ beach seine and bottom trawl; number of standardized sets of gillnets

\begin{tabular}{|c|c|c|c|c|c|c|c|c|c|c|c|c|}
\hline Sampling gear & Site & 2002 & 2003 & 2004 & 2005 & 2006 & 2007 & 2008 & 2009 & 2009-Oct & 2010 & 2011 \\
\hline \multirow[t]{7}{*}{$10 \mathrm{~m}$ beach seine } & Site 1 & 2 & 10 & 10 & 19 & & 3 & 2 & 2 & & 2 & 3 \\
\hline & Site 2 & & 12 & 11 & 7 & 27 & 4 & 6 & 3 & & 11 & 8 \\
\hline & Site $2 \mathrm{~A}$ & & & & & & & 3 & 4 & & & 8 \\
\hline & Site 3 & 4 & 4 & 10 & 20 & 3 & 3 & 4 & 5 & & 9 & 5 \\
\hline & Site $3 \mathrm{~A}$ & 2 & 2 & 15 & 5 & 3 & 3 & 5 & 2 & & 2 & 3 \\
\hline & Site 4 & & & & & & 3 & 3 & 7 & & 3 & 7 \\
\hline & Site $4 \mathrm{~A}$ & & & & & & 3 & 4 & 6 & & 2 & 6 \\
\hline \multirow[t]{5}{*}{$25 \mathrm{~m}$ beach seine } & Site 2 & & & & & & 4 & 4 & 5 & 6 & 4 & 5 \\
\hline & Site $2 \mathrm{~A}$ & & 4 & & & & & 3 & 3 & 6 & 1 & 2 \\
\hline & Site 3 & 4 & 1 & 2 & 5 & 3 & 3 & 4 & 5 & 6 & 5 & 3 \\
\hline & Site 4 & & & & & & 2 & 3 & 4 & 6 & 3 & 4 \\
\hline & Site $4 \mathrm{~A}$ & & & & & & 2 & 1 & 1 & & 1 & 3 \\
\hline \multirow[t]{6}{*}{ Gillnets } & Site 1 & 5 & 1 & 13 & 7 & & 3 & 3 & 4 & & & \\
\hline & Site 2 & & 2 & 2 & 1 & 8 & 3 & 6 & 4 & & 7 & \\
\hline & Site 2A & & & & & & & 3 & 4 & & 3 & \\
\hline & Site 3 & & & 3 & & 2 & 4 & 6 & 10 & & 4 & \\
\hline & Site 4 & & & & & & 3 & 3 & 4 & & & \\
\hline & Site $4 \mathrm{~A}$ & & & & & & 3 & & & & & \\
\hline \multirow[t]{3}{*}{ Bottom trawl } & Site 1 & 1 & & & & & & & & & & \\
\hline & Site 3 & & 2 & 11 & 1 & 4 & 4 & & & & 3 & \\
\hline & Site $4 \mathrm{~A}$ & & & & & & & & & & 1 & \\
\hline
\end{tabular}


Table 3 Summary of the 29 fish species collected in Bonne Bay from 2002 to 2011. $\mathrm{n}$ is the total number of specimens of a species collected. The references indicate studies used to estimate the proportion of mature individuals for each species

\begin{tabular}{|c|c|c|c|c|c|c|}
\hline \multirow{2}{*}{$\begin{array}{l}\text { Family } \\
\text { Species }\end{array}$} & \multirow[b]{2}{*}{ Common name } & \multirow[b]{2}{*}{$n$} & \multirow{2}{*}{$\begin{array}{l}\text { Size } \\
\text { range } \\
(\mathrm{mm})\end{array}$} & \multicolumn{2}{|c|}{ Proportion } & \multirow[b]{2}{*}{ Presence at sites } \\
\hline & & & & $\begin{array}{l}\text { mature } \\
(\%)\end{array}$ & Reference & \\
\hline \multicolumn{7}{|l|}{ Rajidae } \\
\hline Leucoraja ocellata Mitchill & Winter Skate & 10 & $136-590$ & 22 & $\begin{array}{l}\text { Collette and Klein-McPhee } \\
\text { (2002) }\end{array}$ & $2,2 \mathrm{~A}, 3,4,4 \mathrm{~A}$ \\
\hline Amblyraja radiata Donovan & Thorny Skate & 7 & $630-685$ & 100 & Scott and Scott (1988) & $1,3,4$ \\
\hline \multicolumn{7}{|l|}{ Clupeidae } \\
\hline Clupea harengus Linnaeus & Atlantic Herring & 133 & $245-354$ & 98 & Scott and Scott (1988) & $1,2,2 \mathrm{~A}, 3,3 \mathrm{~A}$ \\
\hline \multicolumn{7}{|l|}{ Salmonidae } \\
\hline Salmo salar Linnaeus & Atlantic Salmon & 133 & $25-630$ & 4 & & $1,2,3,3 \mathrm{~A}, 4,4 \mathrm{~A}$ \\
\hline Salvelinus fontinalis Mitchill & Brook Trout & 74 & $34-495$ & 13 & Scott and Scott (1988) & $1,2,2 \mathrm{~A}, 3,4,4 \mathrm{~A}$ \\
\hline \multicolumn{7}{|l|}{ Osmeridae } \\
\hline Osmerus mordax Mitchill & Rainbow Smelt & 474 & $36-205$ & 8 & Scott and Scott (1988) & $1,2,3,3 \mathrm{~A}, 4,4 \mathrm{~A}$ \\
\hline \multicolumn{7}{|l|}{ Gadidae } \\
\hline Gadus morhua Linnaeus & Atlantic Cod & 530 & $23-800$ & 8 & Scott and Scott (1988) & $1,2,2 A, 3,4$ \\
\hline Gadus ogac Richardson & Greenland Cod & 60 & $103-490$ & 55 & Morin et al. (1991) & $1,2,2 A, 3,4$ \\
\hline Merluccius bilinearis Mitchill & Silver Hake & 1 & 215 & 0 & O'Brien et al. (1993) & 3 \\
\hline Microgadus tomcod Walbaum & Atlantic Tomcod & 1 & 200 & 100 & Scott and Scott (1988) & 3 \\
\hline Urophycis tenuis Mitchill & White Hake & 32 & $54-187$ & 0 & Scott and Scott (1988) & $1,2,2 A, 3,4$ \\
\hline \multicolumn{7}{|l|}{ Gasterosteidae } \\
\hline Gasterosteus aculeatus Linnaeus & Threespine Stickleback & 1623 & $12-81$ & 97 & Scott and Scott (1988) & $\begin{array}{l}1,2,2 \mathrm{~A}, 3,3 \mathrm{~A}, 4, \\
4 \mathrm{~A}\end{array}$ \\
\hline Gasterosteus wheatlandi Putnam & $\begin{array}{l}\text { Blackspotted } \\
\text { Stickleback }\end{array}$ & 1389 & $20-71$ & 35 & Craig and Fitzgerald (1982) & $1,2,3,3 \mathrm{~A}, 4,4 \mathrm{~A}$ \\
\hline Apeltes quadracus Mitchill & Fourspine Stickleback & 144 & $21-79$ & 84 & Craig and Fitzgerald (1982) & $3,3 \mathrm{~A}, 4 \mathrm{~A}$ \\
\hline \multicolumn{7}{|l|}{ Syngnathidae } \\
\hline Syngnathus fuscus Storer & Northern Pipefish & 19 & $73-132$ & 74 & Scott and Scott (1988) & $3,4,4 \mathrm{~A}$ \\
\hline \multicolumn{7}{|l|}{ Labridae } \\
\hline Tautogolabrus adspersus Walbaum & Cunner & 4103 & $13-267$ & 55 & Scott and Scott (1988) & $1,2,2 \mathrm{~A}, 3,4,4 \mathrm{~A}$ \\
\hline \multicolumn{7}{|l|}{ Zoarcidae } \\
\hline $\begin{array}{l}\text { Zoarces americanus Bloch \& } \\
\text { Schneider }\end{array}$ & Ocean Pout & 12 & $78-290$ & 0 & Scott and Scott (1988) & $1,2,3$ \\
\hline \multicolumn{7}{|l|}{ Stichaeidae } \\
\hline Ulvaria subbifurcata Storer & Radiated Shanny & 6 & $70-120$ & 75 & Le Drew and Green (1975) & 2 \\
\hline \multicolumn{7}{|l|}{ Pholidae } \\
\hline Pholis gunnellus Linnaeus & Rock Gunnel & 100 & $30-188$ & 62 & Vallis et al. (2007) & $1,2,3,4$ \\
\hline \multicolumn{7}{|l|}{ Ammodytidae } \\
\hline Ammodytes americanus DeKay & American Sandlance & 44 & $103-165$ & 38 & $\begin{array}{l}\text { Collette and Klein-MacPhee } \\
\text { (2002) }\end{array}$ & $1,2,2 \mathrm{~A}, 3,4,4 \mathrm{~A}$ \\
\hline \multicolumn{7}{|l|}{ Scorpaenidae } \\
\hline Sebastes fasciatus Storer & Acadian Redfish & 55 & $228-335$ & 98 & Scott and Scott (1988) & $1,2,2 \mathrm{~A}, 4$ \\
\hline \multicolumn{7}{|l|}{ Cottidae } \\
\hline Hemitripterus americanus Gmelin & Sea Raven & 23 & $70-460$ & 89 & Beacham (1982) & $1,2,3,4$ \\
\hline \multirow[t]{2}{*}{ Myoxocephalus aenaeus Mitchill } & Grubby & 45 & $50-158$ & 62 & Lazzari et al. (1989) & $1,2,2 \mathrm{~A}, 3,4,4 \mathrm{~A}$ \\
\hline & Longhorn Sculpin & 128 & 49-309 & 38 & Scott and Scott (1988) & $1,2,2 \mathrm{~A}, 3,4$ \\
\hline
\end{tabular}


Table 3 Summary of the 29 fish species collected in Bonne Bay from 2002 to 2011. $\mathrm{n}$ is the total number of specimens of a species collected. The references indicate studies used to estimate the proportion of mature individuals for each species (Continued)

\begin{tabular}{|c|c|c|c|c|c|c|}
\hline \multicolumn{3}{|l|}{ Family } & \multirow{2}{*}{$\begin{array}{l}\text { Size } \\
\text { range } \\
(\mathrm{mm})\end{array}$} & \multicolumn{3}{|c|}{ Proportion } \\
\hline Species & Common name & $\mathrm{n}$ & & $\begin{array}{l}\text { mature } \\
(\%)\end{array}$ & Reference & Presence at sites \\
\hline \multicolumn{7}{|l|}{$\begin{array}{l}\text { Myoxocephalus octodecemspinosus } \\
\text { Mitchill }\end{array}$} \\
\hline Myoxocephalus scorpius Linnaeus & Shorthorn Sculpin & 234 & $10-420$ & 10 & Scott and Scott (1988) & $1,2,2 \mathrm{~A}, 3,4,4 \mathrm{~A}$ \\
\hline \multicolumn{7}{|l|}{ Agonidae } \\
\hline Aspidophoroides monopterygius Bloch & Alligatorfish & 7 & $80-115$ & 57 & $\begin{array}{l}\text { Collette and Klein-MacPhee } \\
\text { (2002) }\end{array}$ & 3 \\
\hline \multicolumn{7}{|l|}{ Bothidae } \\
\hline Scophthalmus aquosus Mitchill & Windowpane & 4 & $221-265$ & 67 & Scott and Scott (1988) & 3 \\
\hline \multicolumn{7}{|l|}{ Pleuronectidae } \\
\hline Limanda ferruginea Storer & Yellowtail Flounder & 21 & $146-236$ & 43 & Scott and Scott (1988) & 3 \\
\hline $\begin{array}{l}\text { Pseudopleuronectes americanus } \\
\text { Walbaum }\end{array}$ & Winter Flounder & 1085 & $20-277$ & 3 & Scott and Scott (1988) & $\begin{array}{l}1,2,2 A, 3,3 A, 4, \\
4 A\end{array}$ \\
\hline
\end{tabular}

mesh, with a $9 \mathrm{~mm}$ stretch mesh liner in the cod-end) was used to sample Site 1, Site 3 and Site $4 \mathrm{~A}$ (Table 2). Bottom trawl sampling was conducted during daylight hours with an approximate $10 \mathrm{~min}$ tow duration.

\section{Analyses of fish collections}

Fish assemblages at sampling sites

Cluster analyses using the Jaccard dissimilarity index $\left(\mathrm{J}_{\mathrm{D}}\right)$ were performed with MATLAB 7.12 to determine dissimilarity between fish collections made at each site with the $10 \mathrm{~m}$ and $25 \mathrm{~m}$ beach seines. The Jaccard dissimilarity index was used to compute the pair-wise difference between sampling sites based on the presence and absence of species:

$$
J_{D}=1-\frac{a}{a+b+c}
$$

where $a$ is the joint occurrences of species at site $\mathrm{X}$ and $\mathrm{Y}, b$ is the number of species found only at site $\mathrm{X}$, and $c$ is the number of species found only at site $\mathrm{Y}$. $J_{D}$ ranges from 0 (identical fish collections) to 1 (no common species between fish collections). The Jaccard index was chosen because it is exclusively based on the presence-absence of species and it is therefore less affected by unequal sampling effort among different sites (MacDonald et al. 1984). Cluster analyses of data collected with the bottom trawl and gillnets could not be performed due to the infrequency of sampling with the bottom trawl and variation in mesh sizes of the gillnets deployed.

\section{Results}

Twenty-nine species from 17 families were collected at the seven sites in Bonne Bay from 2002 to 2011 (Table 3). Seven species accounted for $90 \%$ of all fish collected (10,497 specimens): cunner (Tautogolabrus adspersus) (39\%, Figure 6 in Appendix 1), threespine stickleback (Gasterosteus aculeatus) (16\%, Figure 7 in Appendix 2), blackspotted stickleback (Gasterosteus wheatlandi) (13\%, Figure 7 in Appendix 2), winter flounder (Pseudopleuronectes americanus) (10\%, Figure 8 in Appendix 3), Atlantic cod (Gadus morhua) (5\%, Figure 9 in Appendix 4), rainbow smelt (Osmerus mordax) (5\%, Figure 10 in Appendix 5), shorthorn sculpin (Myoxocephalus scorpius) (2\%, Figure 11 in Appendix 6). Twenty-two additional species accounted for the remaining $10 \%$ of fish collected (Table 3 ).

\section{Species richness at sampling sites}

Fish species richness was highest at Site $3(N s p=27)$. The species richness was somewhat lower at Site 2 (Nsp $=21)$, Site $1(N s p=20)$, and Site $4(N s p=20)$. The lowest species richness was observed at sites with lower sampling effort: Site 2A $(N s p=14)$, Site $4 \mathrm{~A}(N s p=13)$, and Site $3 \mathrm{~A}(N s p=7)$. Of the 29 species of fishes collected by sampling, two species were present at all seven sites: winter flounder (Pseudopleuronectes americanus) and threespine stickleback (Gasterosteus aculeatus) (Table 3). Five species were present at all sampling sites except for the barachois at Site 3A: cunner (Tautogolabrus adspersus), brook trout (Salvelinus fontinalis), American sandlance (Ammodytes americanus), grubby (Myoxocephalus aenaeus), and shorthorn sculpin (Myoxocephalus scorpius). Three species were present at all sampling sites except for Site 2A: Atlantic salmon (Salmo salar), rainbow smelt (Osmerus mordax) and blackspotted 
stickleback (Gasterosteus wheatlandi). Atlantic herring (Clupea harengus) was found at all sites except for Site 4 and Site 4A at the inner end of East Arm. Atlantic cod (Gadus morhua) and longhorn sculpin (Myoxocephalus octodecemspinosus) were present at all sites except for the two low salinity sites barachois at Site $3 \mathrm{~A}$ and the river delta at Site 4A. Five species were found only at the river delta at Site 3: silver hake (Merluccius bilinearis), Atlantic tomcod (Microgadus tomcod), alligatorfish (Aspidophoroides monopterygius), windowpane flounder (Scophthalmus aquosus), and yellowtail flounder (Limanda ferruginea). Northern pipefish (Syngnathus fuscus) was found only at the sampling sites with eelgrass beds (Zostera marina), specifically Sites 3, 4 and 4A. Radiated shanny (Ulvaria subbifurcata) was found only at Site 2 (Table 3).

\section{Comparison of fish assemblages among sampling sites}

Seventeen species of the total 29 species were observed in the intertidal zone as revealed by the sampling with the $10 \mathrm{~m}$ beach seine (Table 4). Individuals caught by the $10 \mathrm{~m}$ seine were mostly juvenile stages. Cluster analysis of the fish collections made with the $10 \mathrm{~m}$ beach seine indicated that spatial proximity did not explain species dissimilarity across sites (Fig. 3). Site 2A was most dissimilar $\left(J_{D}=0.75\right)$ from the other sites, because only two species, brook trout (Salvelinus fontinalis) and threespine stickleback (Gasterosteus aculeatus), were collected there. This might be due to the steep bottom slope resulting in a narrow intertidal zone. Sites $3 \mathrm{~A}$ and

Table 4 Fish species collected in the intertidal zone of the seven sites within Bonne Bay using the $10 \mathrm{~m}$ beach seine during the decade 2002 to 2011

\begin{tabular}{|c|c|c|c|c|c|c|c|}
\hline Species \Sites & 1 & 2 & $2 \mathrm{~A}$ & 3 & $3 \mathrm{~A}$ & 4 & $4 \mathrm{~A}$ \\
\hline Clupea harengus & & & & & $x$ & & \\
\hline Salmo salar & $x$ & & & $x$ & $x$ & $x$ & $x$ \\
\hline Salvelinus fontinalis & $x$ & $x$ & $x$ & $x$ & $x$ & $x$ & $x$ \\
\hline Osmerus mordax & $x$ & & & $x$ & $x$ & & $x$ \\
\hline Gadus morhua & $x$ & $x$ & & & & & \\
\hline Gadus ogac & $x$ & & & & & & \\
\hline Urophycis tenuis & $x$ & $x$ & & $x$ & & $x$ & \\
\hline Gasterosteus aculeatus & $x$ & $x$ & $x$ & $x$ & $x$ & $x$ & $x$ \\
\hline Gasterosteus wheatlandi & $x$ & $x$ & & $x$ & $x$ & & $x$ \\
\hline Apeltes quadracus & & & & $x$ & $x$ & & $x$ \\
\hline Tautogolabrus adspersus & $x$ & $x$ & & $x$ & & $x$ & $x$ \\
\hline Pholis gunnellus & $x$ & $x$ & & $x$ & & $x$ & \\
\hline Ammodytes americanus & $x$ & $x$ & & & & & \\
\hline Myoxocephalus aenaeus & $x$ & & & $x$ & & $x$ & \\
\hline Myoxocephalus octodecemspinosus & $x$ & $x$ & & $x$ & & & \\
\hline Myoxocephalus scorpius & $x$ & $x$ & & $x$ & & $x$ & \\
\hline Pseudopleuronectes americanus & $x$ & $x$ & & $x$ & $x$ & $x$ & $x$ \\
\hline
\end{tabular}

4A cluster together and are dissimilar $\left(J_{D}=0.39\right)$ from Sites 1, 2, 3 and 4. This is because Sites $3 \mathrm{~A}$ and $4 \mathrm{~A}$ were shallow low salinity environments with seven species in common (Table 4), including fourspine stickleback (Apeltes quadracus), a species found only in low salinity environments in Bonne Bay. Species from the families Gadidae, Pholidae, Ammodytidae, and Cottidae were not present at low saline intertidal Sites $3 \mathrm{~A}$ and $4 \mathrm{~A}$, while they were present at Sites 1, 2, 3, and 4.

Individuals from 24 species were collected using the $25 \mathrm{~m}$ beach seine (Table 5). Cluster analysis showed that Sites 3 and 4 were the least dissimilar $\left(J_{D}=0.2\right.$, Fig. 4$)$. These two sites had 17 species in common including sea raven (Hemitripterus americanus), a species not caught at other sites using the $25 \mathrm{~m}$ beach seine. Site 2 was the closest in species composition to the cluster formed by Sites 3 and 4. Ocean pout (Zoarces americanus) and radiated shanny (Ulvaria subbifurcata) were caught only at Site 2 and their capture explains the dissimilarity between Site 2 and the cluster of Sites 3 and $4\left(J_{D}=0.35\right)$. Only 10 species were collected at Site $2 \mathrm{~A}$ with the $25 \mathrm{~m}$ beach seine. This explains the dissimilarity between Site $2 \mathrm{~A}$ and Sites 2,3 , and $4\left(J_{D}=0.44\right)$. Site $4 \mathrm{~A}$ is the most dissimilar $\left(J_{D}=0.47\right)$ from the other sites.

\section{Discussion}

Fish assemblages and nearshore habitats in Bonne Bay

Twenty-nine species from 17 families were collected during this baseline survey of the fish fauna of inner Bonne Bay. Fish assemblages determined at the sampling sites reflected species response to the available habitat (Able and Fahay 2010) and not the geographic distance between sites. Cluster analysis grouped together the fish assemblages from the two low salinity sampling sites: the barachois at Site 3A and the river delta at Site 4A. This was explained by the presence of Fourspine stickleback (Apeltes quadracus), a species which is found freshwater and brackish habitats, and by the absence of marine species from the families Gadidae, Zoarcidae, Stichaeidae, Pholidae, Cottidae, Agonidae, and Bothidae.

With salinity, substrate and associated flora also determined the fish assemblages at each site. For instance, the northern pipefish (Syngnathus fuscus) was found only at sites with presence of eelgrass beds (Sites 3, 4, and 4A). The long and thin body of northern pipefish is easily confounded with eelgrass leaves, thus northern pipefish might use eelgrass beds as a refugee from predator, explaining that we observed the species only at sites with eelgrass cover (Collette and Klein-MacPhee 2002). Similarly, three species, rock gunnel (Pholis gunnellus), cunner (Tautogolabrus adspersus), and shorthorn sculpin (Myoxocephalus scorpius), were found only at the four sites with rocky bottom substrate, partly explaining that 


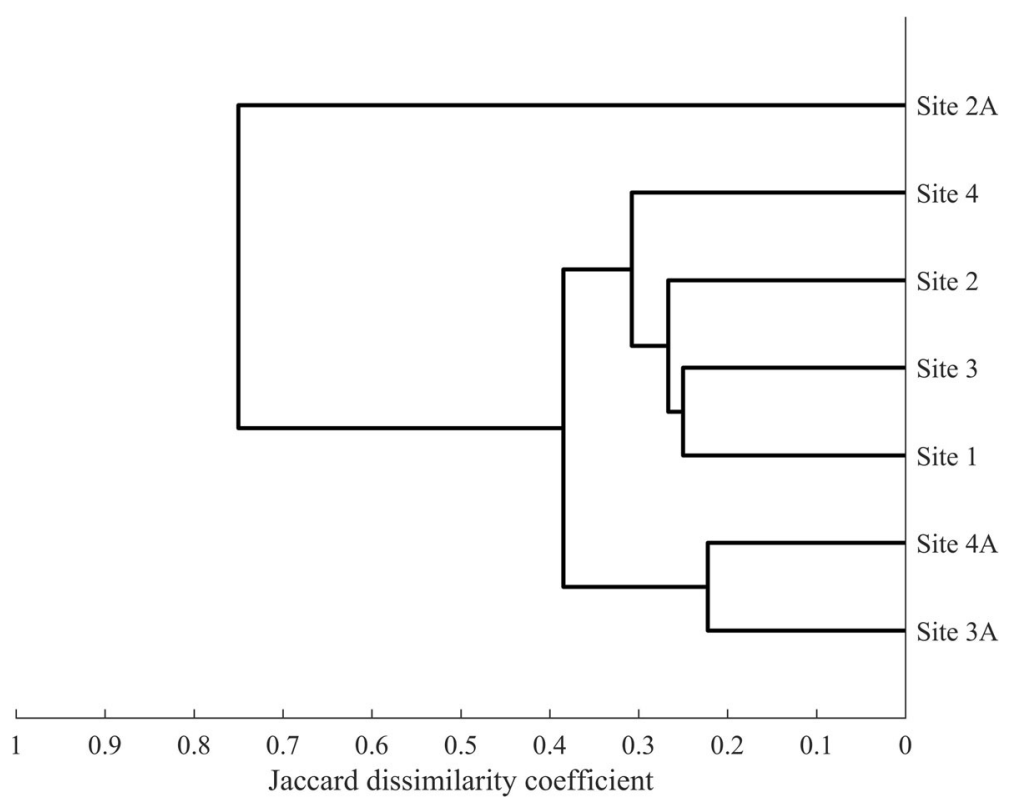

Fig. 3 Dendrogram of dissimilarity in fish assemblages collected in the intertidal zone of Bonne Bay with the $10 \mathrm{~m}$ beach seine

Table 5 Fish species collected in the subtidal zone of five sites within Bonne Bay using the $25 \mathrm{~m}$ beach seine during the decade 2002 to 2011

\begin{tabular}{|c|c|c|c|c|c|}
\hline Species \Sites & 2 & $2 \mathrm{~A}$ & 3 & 4 & $4 \mathrm{~A}$ \\
\hline Leucoraja ocellata & & $x$ & $x$ & $x$ & $x$ \\
\hline Salmo salar & & & $x$ & $x$ & $x$ \\
\hline Salvelinus fontinalis & $x$ & & $x$ & $x$ & $x$ \\
\hline Osmerus mordax & $x$ & & $x$ & $x$ & $x$ \\
\hline Gadus morhua & $x$ & $x$ & $x$ & $x$ & \\
\hline Gadus ogac & & $x$ & & $x$ & \\
\hline Merluccius bilinearis & & & $x$ & & \\
\hline Urophycis tenuis & $x$ & & $x$ & $x$ & \\
\hline Gasterosteus aculeatus & $x$ & $x$ & $x$ & $x$ & $x$ \\
\hline Gasterosteus wheatlandi & $x$ & & $x$ & $x$ & $x$ \\
\hline Apeltes quadracus & & & & & $x$ \\
\hline Syngnathus fuscus & & & $x$ & $x$ & $x$ \\
\hline Tautogolabrus adspersus & $x$ & $x$ & $x$ & $x$ & $x$ \\
\hline Zoarces americanus & $x$ & & & & \\
\hline Ulvaria subbifurcata & $x$ & & & & \\
\hline Pholis gunnellus & $x$ & & $x$ & $x$ & \\
\hline Ammodytes americanus & $x$ & $x$ & $x$ & $x$ & $x$ \\
\hline Hemitripterus americanus & & & $x$ & $x$ & \\
\hline Myoxocephalus aenaeus & $x$ & $x$ & $x$ & $x$ & \\
\hline Myoxocephalus octodecemspinosus & $x$ & $x$ & $x$ & $x$ & \\
\hline Myoxocephalus scorpius & $x$ & $x$ & $x$ & $x$ & \\
\hline Scophthalmus aquosus & & & $x$ & & \\
\hline Limanda ferruginea & & & $x$ & & \\
\hline Pseudopleuronectes americanus & $x$ & $x$ & $x$ & $x$ & $x$ \\
\hline
\end{tabular}

these four sites grouped in the cluster analyses. Interestingly, Site 3 had the most complex substrate with rocky bottom and eelgrass beds, which might explain the higher diversity of fish observed at that site.

\section{Comparison of the fish faunas of Bonne Bay, Newfoundland and Gilbert Bay, Labrador}

While little is known about the inshore fish fauna on the west Coast of Newfoundland, a previous study used the same $10 \mathrm{~m}$ and $25 \mathrm{~m}$ beach seines and gillnets to sample the inshore fish fauna of Gilbert Bay, a Marine Protected Area in southeast Labrador (Wroblewski et al. 2007). This offers the opportunity to compare inshore fish assemblages from coastal embayment south (i.e. Bonne Bay) and north (i.e. Gilbert Bay) of the Strait of Belle Isle, a potential biogeographical boundary (Steele 1975, 1983).

Seventeen species observed in this study were also observed in Gilbert Bay: Atlantic herring (Clupea harengus), Atlantic salmon (Salmo salar), brook trout (Salvelinus fontinalis), rainbow smelt (Osmerus mordax), Atlantic cod (Gadus morhua), Greenland cod (Gadus ogac), white hake (Urophycis tenuis), threespine stickleback (Gasterosteus aculeatus), blackspotted stickleback (Gasterosteus wheatlandi), fourspine stickleback (Apeltes quadracus), ocean pout (Zoarces americanus), rock gunnel (Pholis gunnellus), American sandlance (Ammodytes americanus), sea raven (Hemitripterus americanus), shorthorn sculpin (Myoxocephalus scorpius), alligatorfish (Aspidophoroides monopterygius), and winter flounder (Pseudopleuronectes americanus). 


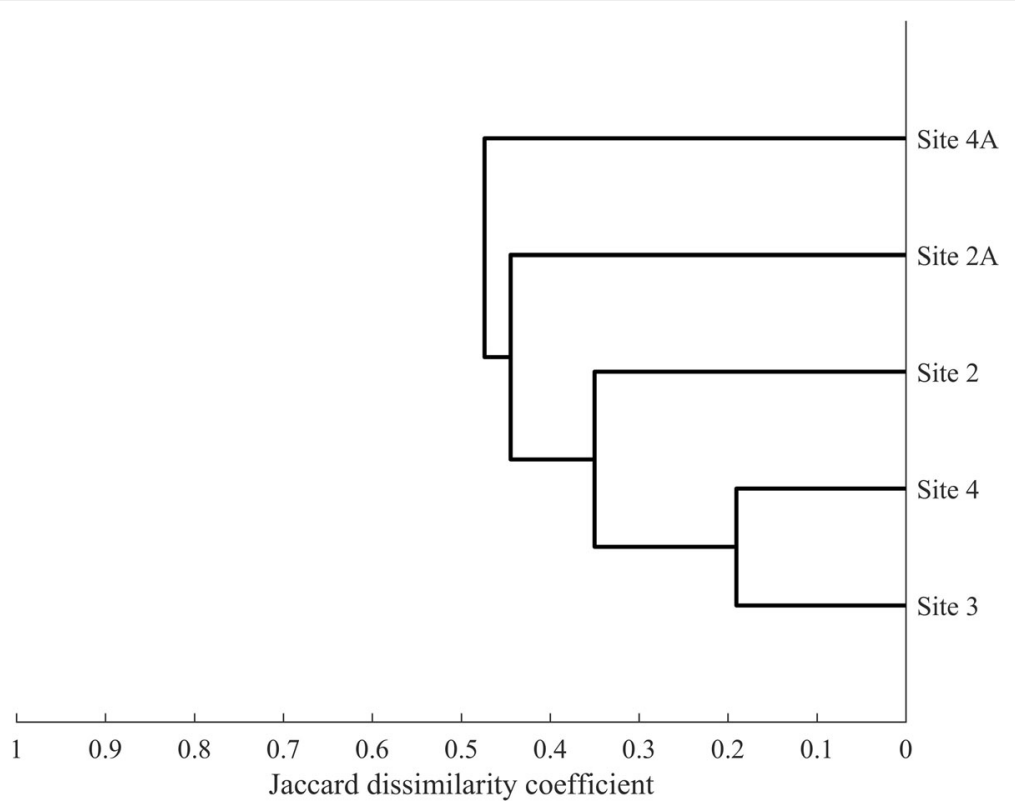

Fig. 4 Dendrogram of dissimilarity in fish assemblages collected in the subtidal zone of Bonne Bay with the $25 \mathrm{~m}$ beach seine

Twelve species present in Bonne Bay were not observed in Gilbert Bay. Out of this 12 species, four have been previously documented north of the Strait of Belle Isle: thorny skate (Amblyraja radiata), Atlantic tomcod (Merluccius tomcod), Acadian redfish (Sebastes fasciatus), and yellowtail flounder (Limanda ferruginea). while eight species, winter skate (Leucoraja ocellata), northern pipefish (Syngnathus fuscus), silver hake (Merluccius bilinearis), cunner (Tautogolabrus adspersus), radiated shanny (Ulvaria subbifurcata), grubby (Myoxocephalus aenaeus), longhorn sculpin (Myoxocephalus octodecemspinosus), and windowpane flounder (Scophthalmus aquosus), have not been documented as present north of the Strait of Belle Isle (Scott and Scott 1988; Collette and Klein-MacPhee 2002).

The Strait of Belle Isle separates the subarctic waters of the Labrador Sea from the cold-temperate
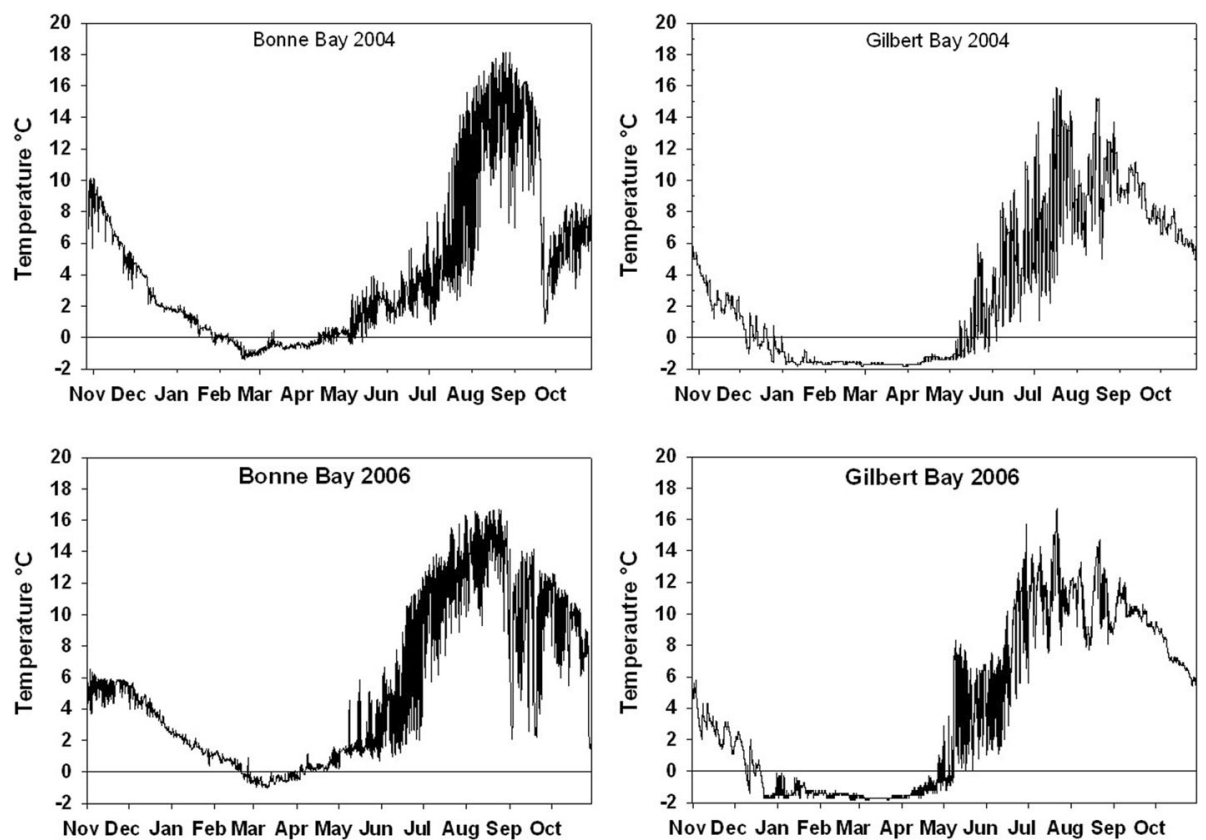

Fig. 5 Seawater temperatures recorded hourly in Bonne Bay (left panels) and in Gilbert Bay (right panels) during 2004 (top panels) and 2006 (bottom panels). The Bonne Bay temperature time series is from $18 \mathrm{~m}$ depth. The Gilbert Bay temperature time series is from $4 \mathrm{~m}$ depth 
waters of the Gulf of St. Lawrence and this was reflected by oceanographic conditions observed in Gilbert Bay and Bonne Bay (Fig. 5). Cold $\left(0-6{ }^{\circ} \mathrm{C}\right)$ Labrador Shelf water enters Gilbert Bay along the bottom at 5-30 m depth (Wroblewski et al. 2007). During the winter months, heat loss from the water column to the atmosphere results in seawater temperatures $<0{ }^{\circ} \mathrm{C}$ throughout the water column and sea ice forms in the Bay (Best et al. 2011). Ice formation along the shoreline begins in October and the bay is usually frozen over by the end December. Gilbert Bay is ice-covered for about five months of the year. In contrast, Gulf of St. Lawrence waters enter inner Bonne Bay by crossing along the bottom of the sill at 5-25 m depth (Richards and de Young 2004). During the late summer Gulf water crossing the sill has a temperature of $16-18{ }^{\circ} \mathrm{C}$. During late winter, heat loss from Gulf surface waters to the atmosphere results in seawater temperatures $<0{ }^{\circ} \mathrm{C}$ throughout the water column. Sea ice may form in the Gulf and in Bonne Bay, depending on the severity of the winter weather.

Observation of water temperature in Gilbert Bay and Bonne Bay in 2004 and 2006, showed that during the winter of 2004 the seawater surface temperature in Bonne Bay declined to $0{ }^{\circ} \mathrm{C}$ in early February, while in Gilbert Bay the seawater surface temperature had already cooled to subzero temperatures 6 weeks earlier (Fig. 5). Seawater surface temperatures rose above $0{ }^{\circ} \mathrm{C}$ by the end of April in Bonne Bay, while the landfast ice covering Gilbert Bay only began to melt in mid-May. The ice covered period varies annually in both bays. For example, in 2006 sea ice appeared in Bonne Bay for only a few weeks in March, while Gilbert Bay was ice covered from mid-December to mid-May (authors' personal observations).

Physiological factors limiting tolerance of low temperature may explain the observed differences. Cunner (Tautogolabrus adspersus), a species abundant in Bonne Bay but absent from Gilbert Bay, is unable to survive prolonged sub-zero seawater temperatures (Scott and Scott 1988). Seawater temperatures in Gilbert Bay are subzero for 5 months of the year (Fig. 5). Mass mortalities of cunner during winter have been observed in Newfoundland coastal waters (Green 1974). We suggest that Tautogolabrus adspersus serves as an indicator species for the biogeographical boundary between the cold-temperate waters of coastal Newfoundland and the subarctic waters of coastal Labrador.

Marine fish species of conservation concern in Bonne Bay Our sampling surveys collected four of species of conservation concern: winter skate, thorny skate,
Atlantic cod and Acadian redfish. Winter skate are extremely rare in the marine waters of the northern Gulf of St. Lawrence (Gauthier and Nozères 2016), and considered "endangered" by COSEWIC (COSEWIC 2015). Yet, we collected ten specimens of winter skate from subtidal waters with sand and gravel bottoms in Deer Arm and East Arm of the Bonne Bay fjord. Based its standard length and maturity, one specimen which we collected (Additional file 1: Photograph 1) exhibited the late-maturing trait of winter skate adapted to waters of the northern Gulf and western coastal Newfoundland (Gauthier and Nozères 2016). Only one specimen of the late-maturing type of winter skate has been recorded in fisheries stock assessment surveys of the northern Gulf (Gauthier and Nozères 2016). That winter skate was collected in a bottom trawl off the southwest coast of Newfoundland in 2008.

We collected seven specimens of thorny skate using gillnets set in subtidal waters at sampling sites in Deer Arm and East Arm. All seven were sexually mature. The thorny skate was assessed by COSEWIC and assigned a status of "special concern" because the species has declined in abundance in the southern Gulf of St. Lawrence, on the Scotian Shelf and on the Grand Banks (COSEWIC 2012d). The thorny skate has a low reproductive potential, and populations recover slowly. There is no commercial fishery in the Gulf targeting thorny skate, but the species is caught as bycatch in fisheries for groundfish using bottom trawls (Wroblewski 2013).

We collected 55 specimens of Acadian redfish using gillnets set in subtidal waters at sampling sites in the East Arm. Almost all specimens collected were sexually mature, many in spawning condition. Our data contributes to the evidence for a resident population of Acadian redfish in Bonne Bay. Genetic and morphometric analyses of specimens caught in Bonne Bay indicate that a population of Acadian redfish exists in Bonne Bay which is reproductively isolated from redfish in the Gulf of St. Lawrence (Valentin 2006). The Acadian redfish population in Bonne Bay is considered an evolutionary significant unit (Sévigny et al. 2007). The population of Acadian redfish living in Bonne Bay has been designated by COSEWIC as "special concern." (COSEWIC 2010) Redfish are caught as bycatch in commercial seining fisheries for mackerel and capelin in Bonne Bay (Wroblewski 2013). Fish species listed as "species-at-risk" often have biological characteristics that make them susceptible to population declines, e.g. a specialized habitat or diet, a small geographic range, or a large body size easily harvested in a fishery (Powles et al. 2000; Hutchings 2001). In the case of Bonne Bay redfish population, the concern is the small geographic range. The redfish population 
is likely confined by the fjord sill to East Arm and Deer Arm of Bonne Bay.

Previous study of local ecological knowledge suggested that similar to redfish, Bonne Bay could support a local population of Atlantic cod (Murray et al. 2008). During our sampling we consistently collected age 0 Atlantic cod indicating that inner Bonne Bay is a nursery ground for Atlantic cod. We also observed Atlantic cod in spawning condition and a homing behaviour to South Arm Bonne Bay (Le Bris et al. 2013). This suggests that age 0 cod collected in Bonne Bay may have been spawned in the South Arm and drifted with the current flowing across the sill into East Arm. However, genetic analysis and population dynamics modelling have suggested that, while local recruitment may occur in Bonne Bay, Atlantic cod observed in Bonne Bay are part of the Northern Gulf of St. Lawrence population and do not form an isolated population (Le Bris 2014).

Finally, it can be noted that two species of wolffish, spotted wolffish (Anarhichas minor) and Atlantic wolffish (Anarhichas lupus), respectively listed as "threatened" and designed as "Special Concern" under SARA (COSEWIC 2012b) (COSEWIC 2012c) have been previously reported during SCUBA diving in Bonne Bay (Hooper 1975) and are sometimes caught in the commercial trap fishery for lobster and snow crab (authors' personal observations). It is likely that these species were not caught in our surveys because they are often associated with boulder habitats, a type of habitat not sampled with our gears.

\section{Conclusions}

Our standardized sampling surveys have shown that there are marine, estuarine and diadromous fish species present in the fjord of Bonne Bay, in western Newfoundland. Fish assemblages reflected the diversity of habitat available in the Bay and included four species of conservation concern. Candidates for National Marine Conservation Area in Canada are assessed based on several criteria including, relative importance for maintaining biodiversity, protecting critical habitats of endangered species, value for ecological research and monitoring, and potential for education and enjoyment. This baseline study of the fish fauna of Bonne Bay contributes the two first criteria. The location of Bonne Bay at the northern end of the distribution range of several fish species should allow the monitoring of the poleward shift of marine species caused by climate change, fulfilling the third criteria. Finally, because of the presence of a University Marine Station and an aquarium, and because of its location adjacent to the Gros Morne National Park, a UNESCO world heritage site with almost 200,000 visitors a year, Bonne provides a unique opportunity to familiarise people with the nearshore marine environment. This is a key element in public support for marine conservation (Vincent 2011). These factors combined with the stewardship attitude of local people are factors that should encourage in the future the full assessment of Bonne Bay as a potential National Marine Conservation Area.

\section{Appendix 1}

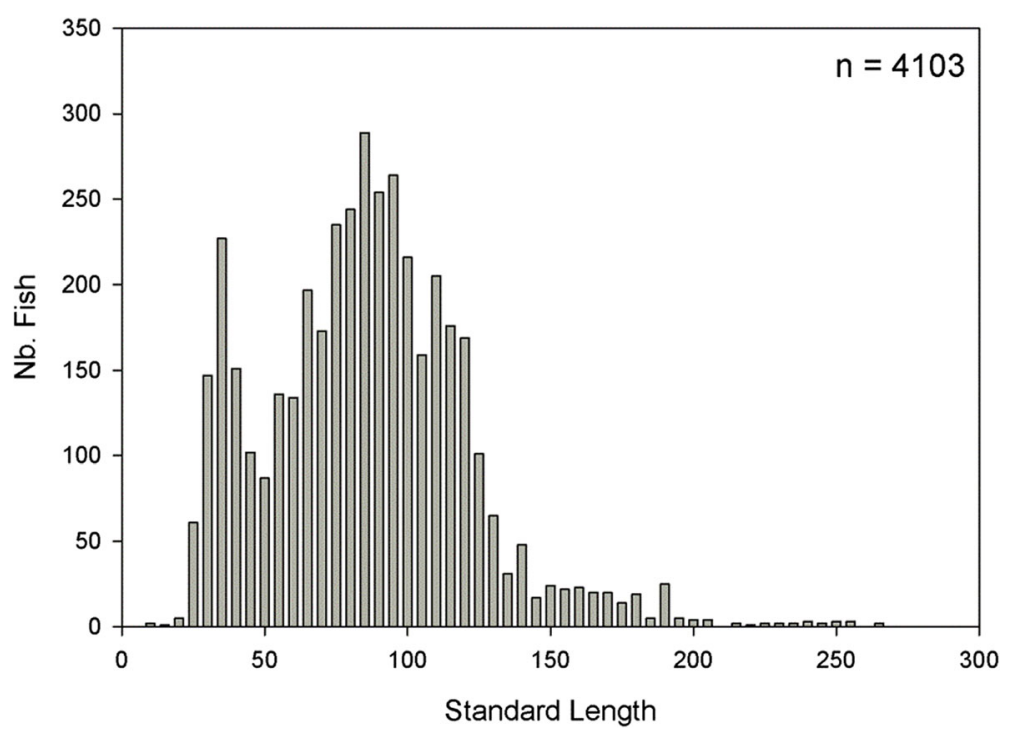

Fig. 6 Length distributions of cunner (Tautogolabrus adspersus) collected in Bonne Bay between 2002 and 2011 using all gear types. $n=$ total number of individuals collected and measured. Standard length is binned into $5 \mathrm{~mm}$ intervals 


\section{Appendix 2}

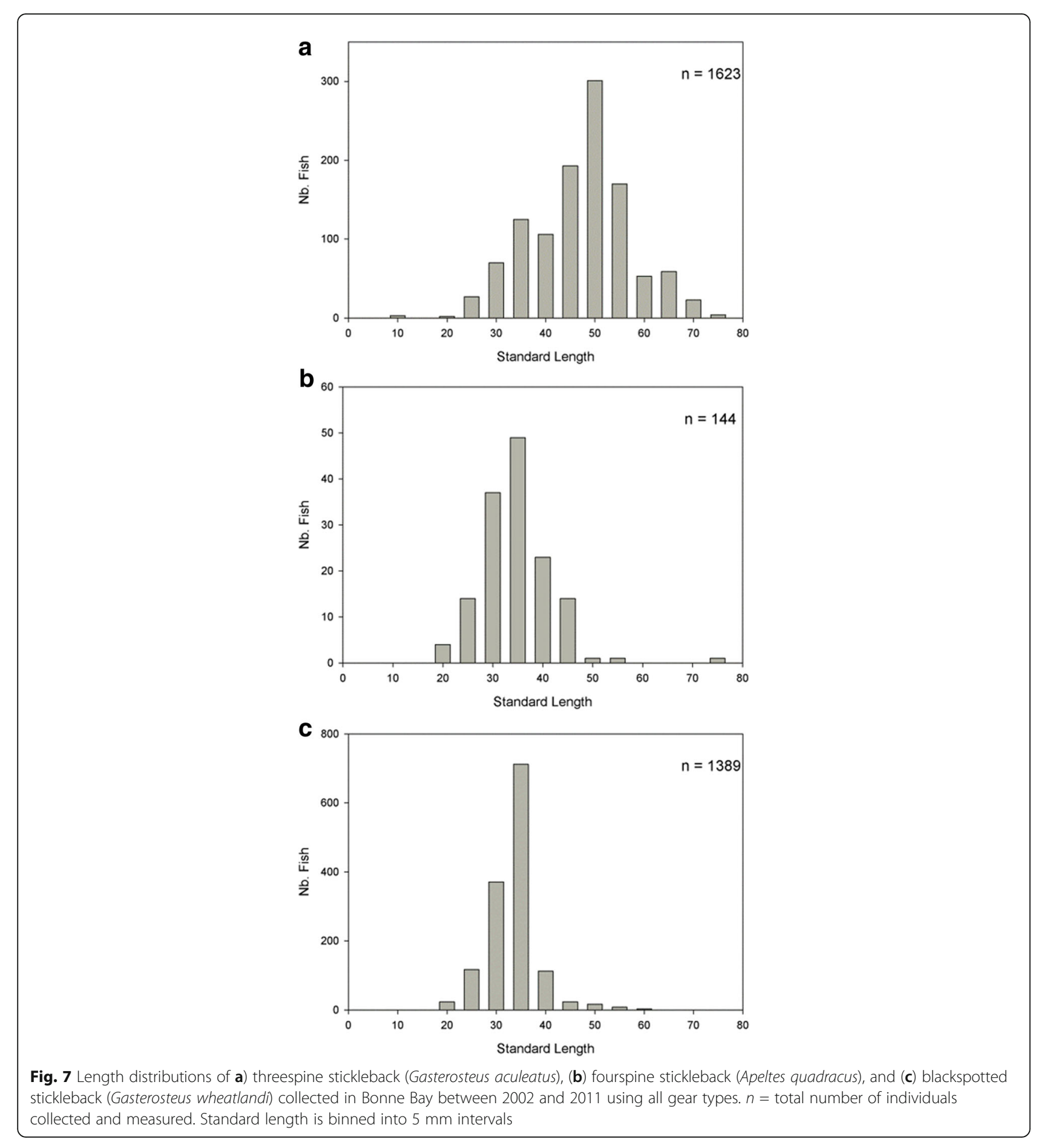




\section{Appendix 3}

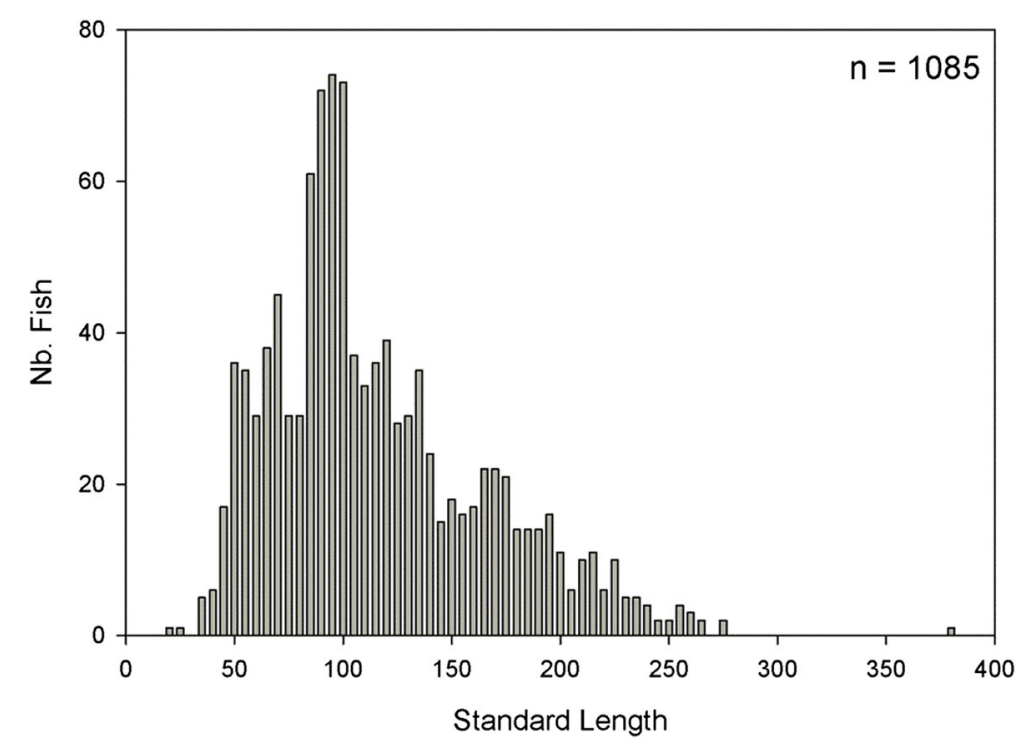

Fig. 8 Length distributions of winter flounder (Pseudopleuronectes americanus) collected in Bonne Bay between 2002 and 2011 using all gear types. $n=$ total number of individuals collected and measured. Standard length is binned into $5 \mathrm{~mm}$ intervals

\section{Appendix 4}

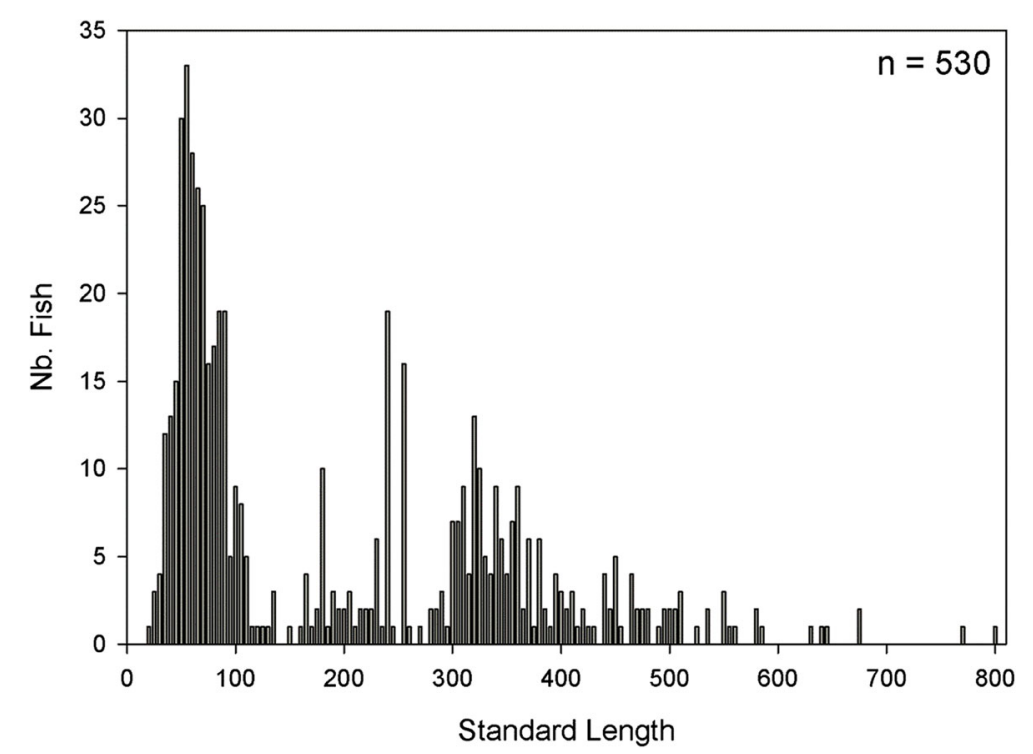

Fig. 9 Length distributions of Atlantic cod (Gadus morhua) collected in Bonne Bay between 2002 and 2011 using all gear types. $n=$ total number of individuals collected and measured. Standard length is binned into $5 \mathrm{~mm}$ intervals 


\section{Appendix 5}

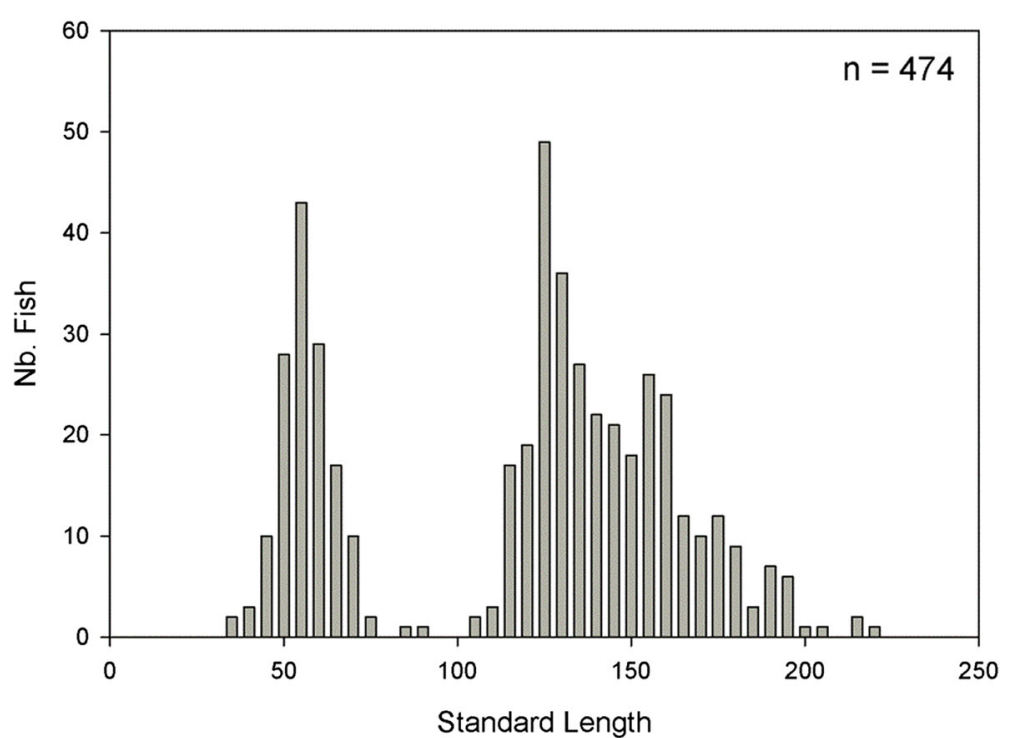

Fig. 10 Length distributions of rainbow smelt (Osmerus mordax) collected in Bonne Bay between 2002 and 2011 using all gear types. $n=$ total number of individuals collected and measured. Standard length is binned into $5 \mathrm{~mm}$ intervals 


\section{Appendix 6}

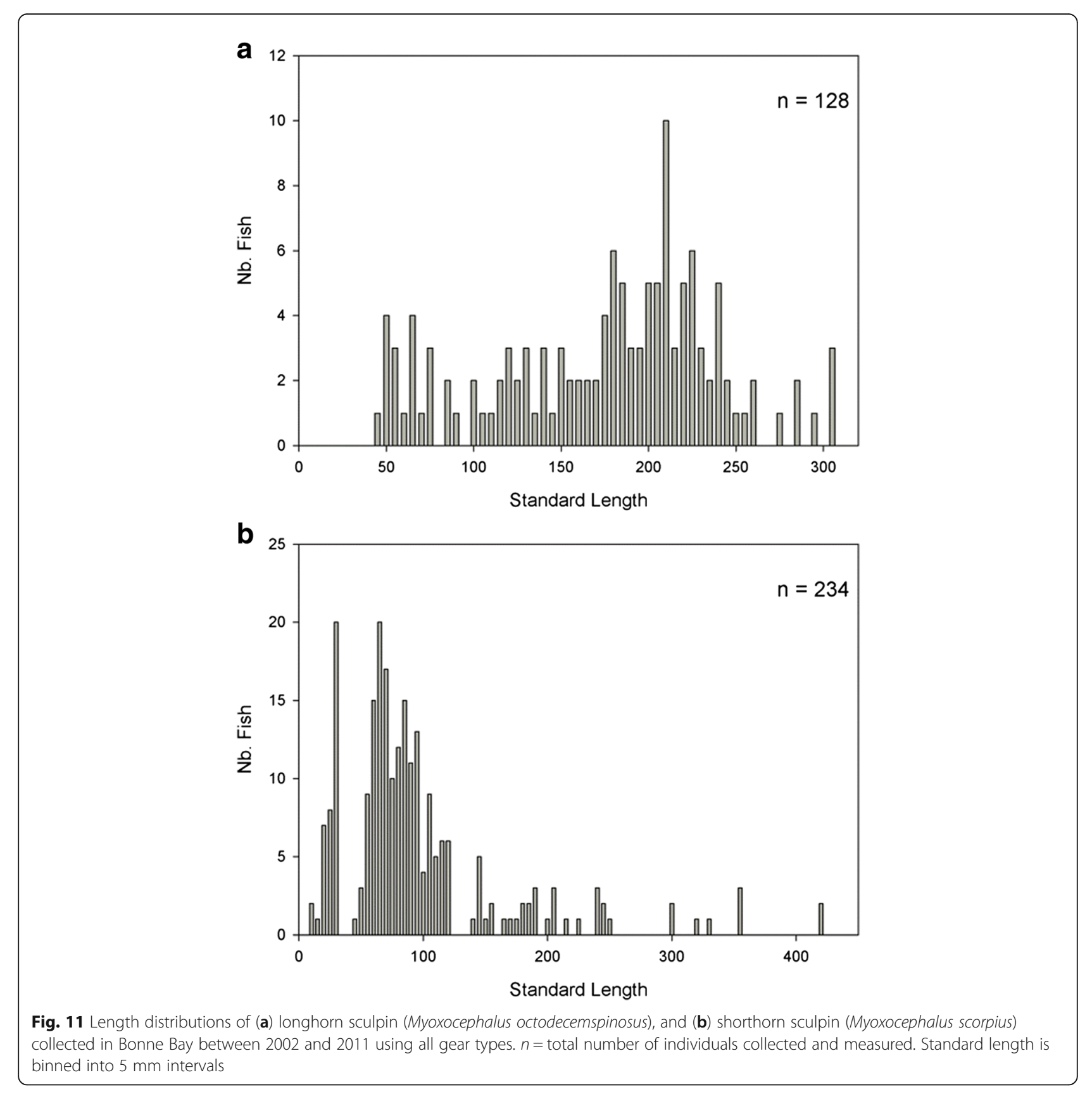




\section{Additional file}

Additional file 1: Photographs. Views of the dorsal (photo 1) and ventral (photo 2) surfaces of an immature male winter skate (Leucoraja ocellata) collected from Bonne Bay on 7 July 2010. The dorsal surface has three or more rows of thorns forming an arrow pattern along the centre of the back (Nozères et al. 2010). The length of this specimen $(54 \mathrm{~cm})$ and size of its claspers indicate this specimen is the late-maturing type, an adaptation to coastal waters of western Newfoundland (Gauthier and Nozères 2016). (ZIP 133 kb)

\section{Abbreviations}

ADCP: Acoustic doppler current profilers; COSEWIC: Committee on the status of endangered wildlife in Canada; CTD: Conductivity-temperature-depth; NMCA: National marine conservation area; SARA: Species at risk act; TL: Total length

\section{Acknowledgements}

The fish survey data presented here were collected by Memorial University undergraduate students and their instructors (Drs. Joe Wroblewski and David Methven) of a field course taught at the Bonne Bay Marine Station in Norris Point, Newfoundland during the summers of 2002-2011. Teaching assistants for the course were Erin Carruthers, Liuming Hu, Arnault Le Bris and Shanshan Liu. The authors wish to acknowledge Dr. Robert Hooper, Director of the Bonne Bay Marine Station, along with Fiona Cuthbert and Allison Eaton, Managers of the Marine Station, for assistance during the field course. Thanks are also extended to Marine Station employees William Coffey and Dennis Rumbolt for boating operations. Dr. Tom Knight and Jennifer Hofman of the Western Newfoundland and Labrador Field Unit of Parks Canada provided information on the anadromous fishes and freshwater fishes inhabiting the rivers and streams of Gros Morne National Park. We thank Dr. Brad deYoung for providing Fig. $2 b$

\section{Funding}

This is a contribution to the Community-University Research for Recovery Alliance (CURRA) project (http://www.curra.ca/about_us.htm). A goal of the CURRA project was to assist fishing communities in the rebuilding of collapsed fish stocks and the recovery of fisheries in the northern Gulf of St. Lawrence. CURRA was funded by the Social Sciences and Humanities Research Council (SSHRC) of Canada and Memorial University, with additional financial and in-kind support from numerous community partners and groups.

Arnault Le Bris was supported by a Graduate Studies Fellowship from Memorial University of Newfoundland and by a grant from the Academic Research Contribution Program (ARCP) of Fisheries and Oceans Canada as a contribution to the CURRA project.

\section{Availability of data and materials}

Photographs of each of the 29 fish species collected by sampling in Bonne Bay are presented in Wroblewski (2013).

\section{Authors' contributions}

The authors participated equally in this research and both approved the final manuscript.

\section{Ethics approval and consent to participate}

Fish sampling and handling protocols were approved by Animal Care Services of Memorial University of Newfoundland.

\section{Competing interests}

The authors declare that they have no competing interests.

\section{Publisher's Note}

Springer Nature remains neutral with regard to jurisdictional claims in published maps and institutional affiliations.

\section{Author details}

${ }^{1}$ Centre for Fisheries Ecosystems Research, Fisheries and Marine Institute of Memorial University of Newfoundland, St. John's, NL A1C 5R3, Canada.
${ }^{2}$ Department of Ocean Sciences, Memorial University of Newfoundland, St. John's, NL A1C 5S7, Canada.

Received: 6 October 2017 Accepted: 9 May 2018

Published online: 19 June 2018

\section{References}

Able KW, Fahay MP. Ecology of estuarine fishes. Temperate waters of the western North Atlantic. Baltimore: The Johns Hopkins University Press; 2010.

Beacham TD. Median length at sexual maturity of halibut, cusk, longhorn sculpin, ocean pout, and sea raven in the Maritimes area of the Northwest Atlantic. Can J Zool. 1982;60:1326-30.

Best S, Lundrigan S, Demirov E, Wroblewski J. Interannual variability of physical oceanographic characteristics of Gilbert Bay: a marine protected area in Labrador, Canada. J Mar Syst. 2011;88:128-38.

Chouinard P-M, Dutil J-D. The structure of demersal fish assemblages in a cold, highly stratified environment. ICES J Mar Sci. 2011;68(9):1896-908.

Collette BB, Klein-MacPhee G. Bigelow and Schroeder's fishes of the Gulf of Maine. 3rd ed. Washington DC: Smithsonian Institution Press; 2002.

COSEWIC. 2005. COSEWIC assessment and update status report on the Fin Whale Balaenoptera physalus in Canada. Committee on the Status of Endangered Wildlife in Canada. Ottawa. ix 37.

COSEWIC. 2006. COSEWIC assessment and update status report on the Harbour Porpoise Phocoena phocoena Northwest Atlantic population in Canada. Committee on the Status of Endangered Wildlife in Canada. Ottawa. vii 32.

COSEWIC. 2010. COSEWIC assessment and status report on the Deepwater Redfish/ Acadian Redfish complex Sebastes mentella and Sebastes fasciatus, in Canada. Committee on the Status of Endangered Wildlife in Canada. Ottawa. x 80.

COSEWIC. 2012a. COSEWIC assessment and status report on the Leatherback Sea Turtle Dermochelys coriacea in Canada. Committee on the Status of Endangered Wildlife in Canada. Ottawa. xv 58.

COSEWIC. 2012b. COSEWIC assessment and status report on the Spotted Wolffish Anarhichas minor in Canada. Committee on the Status of Endangered Wildlife in Canada. Ottawa. x 44

COSEWIC. 2012c. COSEWIC assessment and status report on the Atlantic Wolffish Anarhichas lupus in Canada. Committee on the Status of Endangered Wildlife in Canada. Ottawa. ix 56.

COSEWIC. 2012d. COSEWIC assessment and status report on the Thorny Skate Amblyraja radiata in Canada. Committee on the Status of Endangered Wildlife in Canada. Ottawa. ix 75.

COSEWIC. 2015. COSEWIC assessment and status report on the Winter Skate Leucoraja ocellata, Gulf of St. Lawrence population, Eastern Scotian Shelf Newfoundland population and Western Scotian Shelf - Georges Bank population in Canada. Committee on the Status of Endangered Wildlife in Canada. Ottawa. xvii 46.

Craig D, FitzGerald GJ. Reproductive tactics of four sympatric sticklebacks (Gasterosteidae). Environ Biol Fish. 1982;7:369-75.

deYoung B, Brown KM, Adams RS, McLean SD. Design and deployment of the Bonne Bay observatory. Oceans. 2005;2-3:855-60.

Ennis GP. Closed areas as a conservation strategy in the Newfoundland lobster fishery. Biodiversity. 2011;12:11-20

Gauthier J, Nozères C. Review of winter skate (Leucoraja ocellata) in the northern gulf of St. Lawrence in support of a recovery potential assessment. DFO Can Sci Advis Sec Res Doc. 2016:v:22

Green JM. A localized mass winter kill of cunners in Newfoundland. Can Field Nat. 1974;88:96-7.

Guénette S, Alder J. Lessons from marine protected areas and Integrated Ocean management initiatives in Canada. Coast Manag. 2007;35:51-78.

Hemingway KL, Elliott M. 2002. Field methods. In: Fishes in Estuaries, M Elliott and K Hemingway (eds). Blackwell Science Ltd, Oxford; 410-509.

Hooper RG. Bonne Bay marine resources: an ecological and biological assessment: Parks Canada report, Halifax, Nova Scotia. Contract No. ARO; 1975. p. 74-83.

Hooper RG. A spring breeding migration of the snow crab, Chionoecetes opilio (O Fabr.), into shallow water in Newfoundland. Crustaceana. 1996;50:257-64.

Hutchings JA. Conservation biology of marine fishes: perceptions and caveats regarding assignment of extinction risk. Can J Fish Aquat Sci. 2001;58:108-21.

Lazzari MA, Able KW, Fahay MP. Life history and food habits of the grubby, Myoxocephalus aeneus (Cottidae), in a cape cod estuary. Copeia. 1989;1:7-12.

Le Bris A. 2014. Mechanisms and consequences of variation in the migratory behaviour of Atlantic cod (Gadus morhua L.) in the northern Gulf of St. 
Lawrence. PhD thesis, Biology Department, Memorial University of Newfoundland, NL.

Le Bris A, Fréchet A, Galbraith PS, Wroblewski JS. Evidence for alternative migratory behaviours in the northern gulf of St Lawrence population of Atlantic cod (Gadus morhua L.). ICES J Mar Sci. 2013;70:793-804.

Le Drew BR, Green JM. Biology of the radiated shanny UIvaria subbifurcata Storer in Newfoundland (Pisces: Stichaeidae). J Fish Biol. 1975;7:485-95.

MacDonald JS, Dadswell MJ, Appy RG, Melvin GD, Methven DA. Fishes, fish assemblages, and their seasonal movements in the lower bay of Fundy and Passamaquoddy Bay, Canada. Fish Bull. 1984;82:121-39.

Methven DA, Haedrich RL, Rose GA. The fish assemblage of a Newfoundland estuary: diel, monthly, and annual variation. Estuar Coast Shelf Sci. 2001;52:669-87.

Morin B, Hudon C, Whoriskey F. Seasonal distribution, abundance, and life-history traits of Greeenland cod, Gadus ogac, at Wemindji, eastern James Bay. Can J Zool. 1991:69:3061-70.

Murray G, Neis B, Palmer CT, Schneider DC. Mapping cod: fisheries science, fish harvesters' ecological knowledge and cod migrations in the northern gulf of St. Lawrence. Hum Ecol. 2008;36:581-98.

Nozères C, Archambault D, Chouinard P-M, Gauthier J, Miller R, Parent E, Schwab P, Savard L, Dutil J-D. Identification guide for marine fishes of the estuary and northern gulf of St. Lawrence and sampling protocols used during trawl surveys between 2004 and 2008. Can Tech Rep Fish Aquat Sci. 2010;2866:243.

O'Brien L, Burnett J, Mayo RK. Maturation of nineteen species of finfish off the northeast coast of the United States, 1985-1990. Natl Oceanic Atmos Adm Tech Rep Natl Mar Fish Ser. 1993:113:66.

Parks Canada Agency. State of Canada's natural and historic places 2011. Ottawa: Parks Canada; 2011

Parsons LS. Management of Marine Fisheries in Canada. Can Bull Fish Aquat Sci. 1993;225

Pottle RA, Green JM, Martel G. Dualistic spawning behavior of the cunner, Tautogolabrus adspersus (Pisces: Labridae) in Bonne Bay, Newfoundland. Can J Zool. 1981;59:1582-5.

Powles H, Bradford MJ, Bradford RG, Doubleday WG, Innes S, Levings CD. Assessing and protecting endangered marine species. ICES J Mar Sci. 2000; 57:669-76.

Quijon PA, Snelgrove PVR. Predation regulation of sedimentary faunal structure: potential effects of a fishery-induced switch in predators in a Newfoundland sub-Arctic fjord. Oecologia. 2005;144:125-36.

Richards C, de Young B. Analysis of physical oceanographic data from Bonne Bay, September 2002 - September 2004. Physics and physical oceanography data report 2004-1. St. John's: Memorial University of Newfoundland; 2004

Scott WB, Scott MG. Atlantic fishes of Canada. Toronto: University of Toronto Press; 1988.

Sévigny J-M, Méthot R, Bourdages H, Power D, Comeau P. Review of the structure, the abundance and distribution of Sebastes mentella and $\mathrm{S}$. Fasciatus in Atlantic Canada in a species-at-risk context: an update. Can Sci Advis Secr Res Doc. 2007;200:085.

Shaw J. Submarine moraines in Newfoundland coastal waters: implications for the deglaciation of Newfoundland and adjacent areas. Quat Int. 2003;99-100: $115-34$.

South GR, Hooper RG. A catalogue and atlas of the benthic marine algae of the island of Newfoundland: Memorial University of Newfoundland, St. John's, Newfoundland: Occasional Papers in Biology; 1980.

Steele DH. Marine climate and the biogeography of surface waters in the Northwest Atlantic. Le naturaliste Canadien. 1975;102:189-98.

Steele DH. Marine ecology and zoogeography. In: South GR, editor. Biogeography and ecology of the island of Newfoundland. The Hague: Dr. W. Junk Publishers; 1983. p. 421-65.

Valentin A. Structure des populations de sébaste de l'Atlantique du Nord-Ouest dans un contexte de gestion des stocks et d'évolution. QC: PhD thesis, Institut des sciences de la mer, Université du Québec à Rimouski; 2006.

Vallis L, MacLatchy DL, Munkittrick KR. Assessment of the potential of the rock gunnel (Pholis gunnellus) along the Atlantic coast of Canada as a species for monitoring the reproductive impacts of contaminant exposures. Environ Monit Assess. 2007;128:183-94.

Vincent ACJ. Saving the shallows: focusing marine conservation where people might care. Aquat Conserv Mar Freshwat Ecosyst. 2011;21:495-9.

Wroblewski J. Marine wildlife of the Gros Morne National Park Region. St. John's: Breakwater Books; 2013. p. 202.

Wroblewski JS, Kryger LK, Methven DA, Haedrich RL. The fish fauna of Gilbert Bay, Labrador: a marine protected area in the Canadian subarctic coastal zone. J Mar Biol Assoc U K. 2007;87:575-87.

\section{Ready to submit your research? Choose BMC and benefit from:}

- fast, convenient online submission

- thorough peer review by experienced researchers in your field

- rapid publication on acceptance

- support for research data, including large and complex data types

- gold Open Access which fosters wider collaboration and increased citations

- maximum visibility for your research: over $100 \mathrm{M}$ website views per year

At BMC, research is always in progress.

Learn more biomedcentral.com/submissions 